\title{
FEATURE
}

\section{Whose Decline?}

\section{Which Academic Libraries}

are "Deserted" in Terms of Reference Transactions?

\section{Rachel Applegate}

Rachel Applegate is Assistant Professor, Indiana University School of Library and Information Science, Indianapolis. Submitted for review June 19, 2007; accepted for publication September 28, 2007.
Reference \& User Services Quarterly, vol. 48, no. 2, pp. 176-189

(c) 2008 American Library Association. All rights reserved.

Permission granted to reproduce for nonprofit, educational use.
This study examines reference transaction quantities reported through the Academic Library Survey of the National Center for Educational Statistics to explore whether, and the extent to which, academic libraries are seeing a decline: the beginnings of a "deserted library." Data from 2002 and 2004 shows a decline in reference transactions per week on a per-library basis and on a perstudent basis, but this decline differs by the type of institution (Carnegie Class). Librarians at master's institutions have actually seen an increase in the numbers of questions per librarian. ARL institutions' patterns differ from those of other universities, which calls into question using ARL experiences as indicative of the wider academic universe.

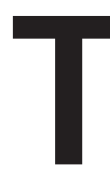

he Deserted Library" - a headline in the Chronicle of Higher Education. Much commentary, and some research, has addressed the topic of trends in usage of academic libraries. A decline in use of the physical academic library is seen by some commentators as an inevitable result of changes in the information landscape and in student, particularly undergraduate, information-seeking habits.

An underappreciated aspect of this issue is that just as not all libraries are alike, not all academic libraries are alike.
True, one organization, the Association of College and Research Libraries (ACRL), serves libraries at community, baccalaureate, master's, doctoral, and research institutions. However, some types of libraries are more often the site of published research than others. Association of Research Libraries (ARL) members are identifiable, organized, and have been committed for decades to extensive data-gathering. That makes their existence (for surveys) and their data a treasure trove for researchers interested in academic library issues. However, is the ARL perspective a reasonable representation of all academic librarianship? How representative is this group? Analysis of data about reference transactions from a much broader data pool suggests that ARL experiences may be disproportionately affecting the representation of the "decline" issue.

\section{LITERATURE REVIEW}

Writings on the possible decline in use of academic libraries include anecdotal or personal opinions or perspectives or broad, data-based research. Some authors argue or show that there is a decline; others that there is not. The "decline" expression that crystallized and sparked much of the debate was offered in a 2001 article by a reporter, 
Scott Carlson. The title and the publication venue say it all_" "The Deserted Library," on the front page of the Chronicle of Higher Education. ${ }^{1}$ The Chronicle is the premier news source for academia in general, and is read by administrators and faculty as a key information source for what is going on in their world. A direct counter argument was provided in Library Journal by Andrew Albanese. ${ }^{2}$ Drawing upon his contacts with staff at a number of individual libraries, he argues that usage has increased (although he did not conduct any systematic research to verify the representativeness of these observations).

Charles Martell's 2005 editorial in the academic library journal portal: Libraries and the Academy presents a neat summary of the issue and uses ARL statistics to argue that reference usage has indeed declined. ${ }^{3}$ On the other side, in a review written specifically for nonlibrarian academics, Barbara Fister argues against the "myth" of the nonimportance of the physical library in the lives of undergraduates on the basis of personal observations (she is a director at a small, liberal arts college with mainly residential, traditional-aged students). ${ }^{4}$ Currently each side has some data to support its statements about library traffic. The ARL statistics center clearly shows a decline in reference (4.5 percent average annual decline, 1991-2005) and in circulation transactions (1.2 percent decline per year). ${ }^{5}$ On the other hand, a systematic and comprehensive survey of new or renovated academic library facilities showed consistent gains in usage. ${ }^{6}$

Interestingly, an ACRL task force looking into academic libraries' future did not list a decline in use as one of their top ten assumptions for the future. The following items listed do not seem to anticipate any declines and in fact seem to predict increases: "Distance learning will be an increasingly more common option in higher education, and will coexist but not threaten the traditional bricks-and-mortar model," "Students and faculty will increasingly demand faster and greater access to services," and "The demand for technologyrelated services will grow and require additional funding."

What is not often a feature of the analysis or a subdivision of the data are the distinctive characteristics of the libraries involved. ARL library researchers and issues are well-represented in library literature. Yet college, university, and research libraries do show distinct differences, and not just in the most elemental and traditional measurement of a "research library" — collection strength. Collection variables represent three (or four) of the five data elements for the membership-defining
ARL Index: number of volumes held, number of volumes added (gross), and number of current serials received. The others are total operating expenditures and number of professional plus support staff. ${ }^{8}$

A recent study of library staffing has demonstrated the reality of these by-type differences. ${ }^{9}$ It showed that staffing at doctorate granting institutions (both public and private) differs from those offering only master's and baccalaureate degrees in ratios of librarians to patrons. Doctoral intensive and doctoral extensive (Carnegie classifications) institutions have the lowest instructional employee to librarian ratios of all institutional types (that is, each librarian potentially serves fewer faculty on average). There are more "other staff" per librarian in doctoral institutions than in master's or baccalaureate institutions (that is, a smaller percentage of a doctoral institution's library staff are librarians). Those statements are generally accurate for both public and private institutions. For private doctoral extensive institutions, there are far fewer students per librarian; for public doctoral universities, the student-faculty ratio is more similar to other types of institutions.

From these conclusions it is plausible to assume that library traffic also may well be affected by a library's specific mission and focus, as well as the characteristics of the library's parent institution in terms of student body, faculty roles, and its own strategic positioning with respect to physical versus virtual education. Much of this institutional differentiation is reflected in Carnegie institutiontype classifications and in "control" classifications (the governance structure of either public, private not-for-profit, or private for-profit).

There is a need for more data to answer the question, is library use really declining? If so, does the decline vary by type of library? This study examines reported reference transactions from 2002 and 2004 (the main dependent variable) and analyzes differences among institution types (the main independent variable).

"Reference transaction" quantification is not unambiguous. The recording of reference transaction volume has existed for quite some time (at least since 1947) with the most important and systemic approach taken in 1976-77 by the Library Administration Division of the American Library Association along with the U.S. Department of Education to determine questions for the "HEGIS/LIBGIS" federal survey. ${ }^{10}$ It defined a reference transaction as one that involves "information sources" and the "library staff" (see appendix for the current and original definitions).

Writing about the process of reference 
transaction tallying has taken several forms. In one form, different variations for sampling are examined for those libraries not engaged in continuous tallying. ${ }^{11}$ In another, different categorization schemes for transactions are proposed. ${ }^{12}$

There are a few studies that take a step back and explicitly acknowledge and discuss the challenges of recording reference transactions. In public libraries a thorough self-reflective study showed that reference staff members had widely diverging categorizations of question types. ${ }^{13}$ Shontz examined the process in detail in a school library setting, remarking that while the categorization seemed effective, merely finding time for and remembering to mark the tallies was difficult for her participants. ${ }^{14}$ The 2002 SPEC kit (a survey and compilation of practices by ARL members) on reference service statistics described a variety of methodologies, mainly paper-based (even in 2002), and just less than half not continuous throughout the year. ${ }^{15}$

More frequently, however, the act of tallying is not described in any detail, nor its complexities, reliability, or validity discussed. Richardson's review of "the current state of research on reference transactions" in 2002 gives witness to a consistent assumed reality (reification) of the "transaction," with phrases like "analyzing 1,000 questions asked," "50,000 reference questions were asked," and "658 second-level reference questions." ${ }^{16}$ Most of this review examined studies of the components of the transaction or of the persons involved on either side, rather than exploring the idea of a "quantum" (discrete, separate) reference transaction or its quantification. Saxton and Richardson produced an intensive and extensive study of reference transactions, but even this did not examine the transaction per se; while their study stated that 15 percent of transactions in each study hour were not recorded, it does not describe how that measure of unreliability was determined. ${ }^{17}$

More commonly, the nature of the data is simply taken as self-evident and an author goes on to use the data as an independent or dependent variable. For example, Murfin used reference transactions first to study and then to predict staffing needs. ${ }^{18}$ Shapiro related reference transactions to performance measurement, as did Weiner fifteen years later, both in the context of ARL library evaluation. ${ }^{19}$ Lochstet and Lehman found such a high correlation between gate count and reference transactions that they ended up advocating replacement of the "increasingly unfeasible" reference transaction tally by the proxy of gate count. ${ }^{20}$ An unusual exception is the approach taken by Dole, Hurych, and Liebst, who interviewed library administrators about the usefulness of particular data and found they considered reference transaction data to be unimportant for decision-making. ${ }^{21}$

\section{METHOD}

The present study is based on the "number of reference transactions in a typical week" question that is a part of the Academic Library Survey (ALS) administered by the National Center for Education Statistics (NCES). The same question and tally appear in the ARI's statistics and the ACRI's own survey. All surveys use the same definition of a reference transaction.

Like most other research, this study avoids an intense examination of the nature and reliability of the recording of "a" reference transaction. Instead, it acknowledges these assumptions:

- The designers of the ARL, ACRL, and ALS/ NCES surveys believe that reference transactions can be reported as a realistic figure representing service quantity for a typical week, not an average week. (A small-scale study has shown that these reported typical week quantities are significantly larger than a semester's total divided by 16). ${ }^{22}$

- Essentially all of the libraries who report reference transaction amounts to ARL, ACRL, and ALS/NCES surveys do so in good faith. When estimates are made, they represent an honest attempt to represent real amounts of transactions (services rendered).

- If there is a systemic bias present in the data (for example, if institutions exaggerate the quantity of services rendered), it is presumed either to be consistent across all participants or randomly distributed, and it is assumed not to differ by type of institution. This is debatable, but with the existing data this kind of bias is undetectable.

Two basic research questions drive the current study: First, is there a decline in reference transaction activity (a use of libraries or library services) in U.S. academic libraries as reported on the Academic Library Survey? Second, does reference transaction activity and its decline or increase differ according to the type of institution?

The first is a descriptive "prevalence" question. The second is a descriptive "causal" question (descriptive because no experimental manipulation is involved; causal because it is assumed that any association between type of institution and reference activity is in the direction of institution type influencing reference activity rather than the 
reverse). The following is a list of measures used to examine the two questions posed:

- Overall numbers of reference transactions per library that describe what a particular institution (as a unit) is experiencing. (Per library is the most common unit of analysis for many library statistics.)

- Ratio of reference transactions per week to the number of students enrolled. This adjusts for changes in student population sizes at particular institutions. If reference transaction volume increases, but not as fast as the size of the student body, then it is an actual decrease, even if the institution itself (the library) experiences increased traffic.

- Reference transactions per week per librarian (librarians only, not other professionals or other staff). This is a limited way to gain a perspective on the experience of the average or typical individual librarian. Are librarians handling more reference questions because there are fewer librarians or more questions?

The data for this study comes from a compilation of Academic Libraries Survey data for 2002 and 2004, available from the National Center for Education Statistics' "Compare Academic Libraries" webpage. ${ }^{23}$ An initial pool of data was created, then it was reviewed and revised before the independent and dependent variables were extracted. The original data pool consisted of doctorate-, masters-, and baccalaureate-granting institutions (Carnegie classes in the 10,20, and 30 groupings) who reported reference transaction data in the ALS for both 2002 and 2004. ARL institutions were identified and are separated from the doctoral grouping, which therefore includes only non-ARL doctoral institutions. An attempt was made to identify institutions where apparent errors were made in data collection, definition, or transmission. Small errors are essentially undetectable. The identification here is based upon outliers-values that would be very unusual, if not impossible, in real life. The following were identified as outliers:

- Institutions with increases in reference transactions of more than 100 percent or decreases of more than 50 percent (more than doubled, or declined more than half).

- Institutions reporting reference transactions where there are more than one per full-time equivalent (FTE) student in 2002 or 2004. That is, an institution with one thousand students would see one thousand reference transactions per week, an institution with ten thousand students would see ten thousand reference transactions per week, and so forth. The FTE student figure in the ALS database is derived from IPEDS (Integrated Postsecondary Educational Data System) data, not from the library survey. It is assumed that anomalous ratios are the result of errors in the reference transaction figures reported, not the FTE student enrollment.

- Institutions with fewer than .01 reference transactions per FTE student in 2002 or 2004. For example, an institution with one thousand students would see fewer than ten reference transactions per week, an institution with ten thousand students would see fewer than one hundred reference transactions per week, etc.

The final data pool included 979 institutions (see table 1).

Table 2 shows that between 15 and 22 percent of all institutions had data that so differed from the criteria above as to qualify as an outlier. This can seem like a large proportion of problematic data.
Table 1. Institutions Included in the Study

\begin{tabular}{lcc}
\hline Type of institution & $\boldsymbol{n}$ & $\begin{array}{c}\text { FTE students } \\
\text { enrolled }\end{array}$ \\
ARL & 76 & $1,747,678$ \\
Doctoral-non ARL & 111 & $1,272,708$ \\
Master's & 417 & $2,266,993$ \\
Baccalaureate & 375 & 660,464 \\
Total & 979 & $5,947,843$ \\
\hline
\end{tabular}

Table 2. Institutions Excluded as Outliers

\begin{tabular}{lcc}
\hline Type of institution & Excluded & $\begin{array}{c}\text { Percent of } \\
\text { Institution Type } \\
\text { Excluded }\end{array}$ \\
ARL & 13 & 15 \\
Doctoral-non ARL & 31 & 22 \\
Master's & 100 & 19 \\
Baccalaureate & 69 & 16 \\
Total & 213 & 18 \\
\hline
\end{tabular}


Figure 1. Percent Change in Reference Transactions Per Week Per Library as Percent of 2002

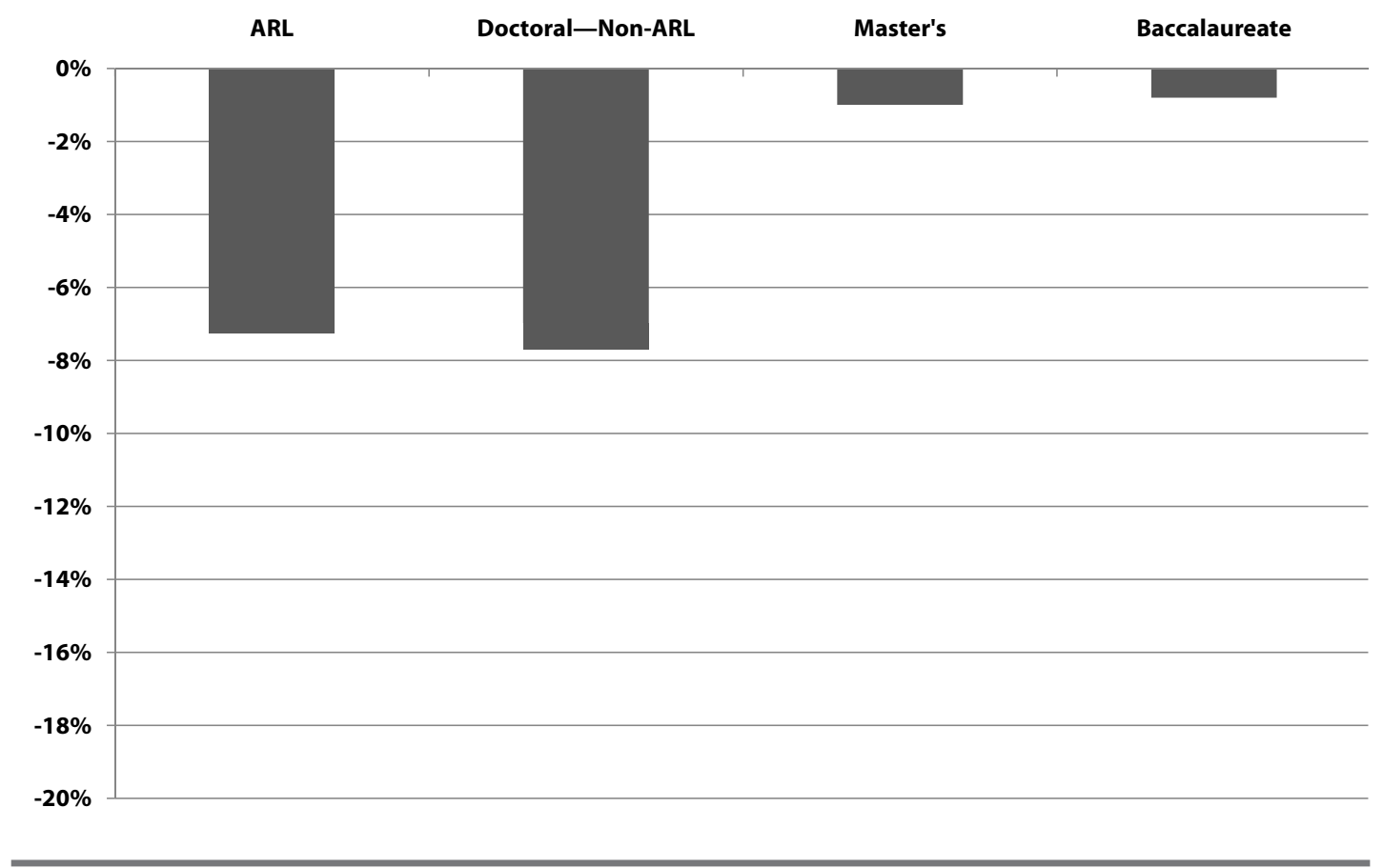

Table 3. Change in Average Number of Reference Transactions per Week per Library

\begin{tabular}{lcccc}
\hline & & & \multicolumn{2}{c}{$\mathbf{9 5 \%}$ Confidence Interval } \\
$\begin{array}{l}\text { Type of } \\
\text { Institution }\end{array}$ & Average Change & $\begin{array}{c}\text { Standard } \\
\text { Deviation }\end{array}$ & Lower & Upper \\
ARL & $-7.3 \%$ & $28.2 \%$ & $-13.7 \%$ & $-0.8 \%$ \\
$\begin{array}{l}\text { Doctoral-non } \\
\text { ARL }\end{array}$ & $-7.7 \%$ & $30.3 \%$ & $-13.4 \%$ & $-2.0 \%$ \\
Masters & $-1.0 \%$ & $28.0 \%$ & $-3.7 \%$ & $1.7 \%$ \\
Baccalaureate & $-0.8 \%$ & $27.0 \%$ & $-3.5 \%$ & $1.9 \%$ \\
Total & $-2.2 \%$ & $28.0 \%$ & $-3.9 \%$ & $-0.4 \%$ \\
\hline
\end{tabular}

A large source of error may simply be the format of the question, as "per week." Libraries keeping continual tallies need to either select a specific typical week or derive an average. Survey experience suggests that questions involving arithmetic are difficult for respondents. ${ }^{24}$ Another explanation may be that different libraries may have more difficulty identifying all service points, involving all personnel, and doing both consistently in each survey year. The lack of research on the reliability of transaction tallying leaves large questions. However, given that more than 90 percent of American academic libraries completed the survey, the 82 percent of libraries that have non-outlier data leaves a large final data set of approximately 75 percent of this universe.

Importantly, one overall assumption for the study - that the data-gathering process's strengths and weaknesses are relatively consistent across types of institutions is supported by the fact that the rate of disqualification or of being an outlier on any of these variables-is not statistically significantly different by type of institution (by a chi $^{2}$ test), though ARL and baccalaureate institutions show a somewhat lower rate (table 2). This might be because of ARL institutions having the advantage of more robust and established reporting systems and baccalaureate institutions having more hands-on services, but the differences are relatively minor. 
Figure 2. Average Reference Transactions Per Week Per FTE Student

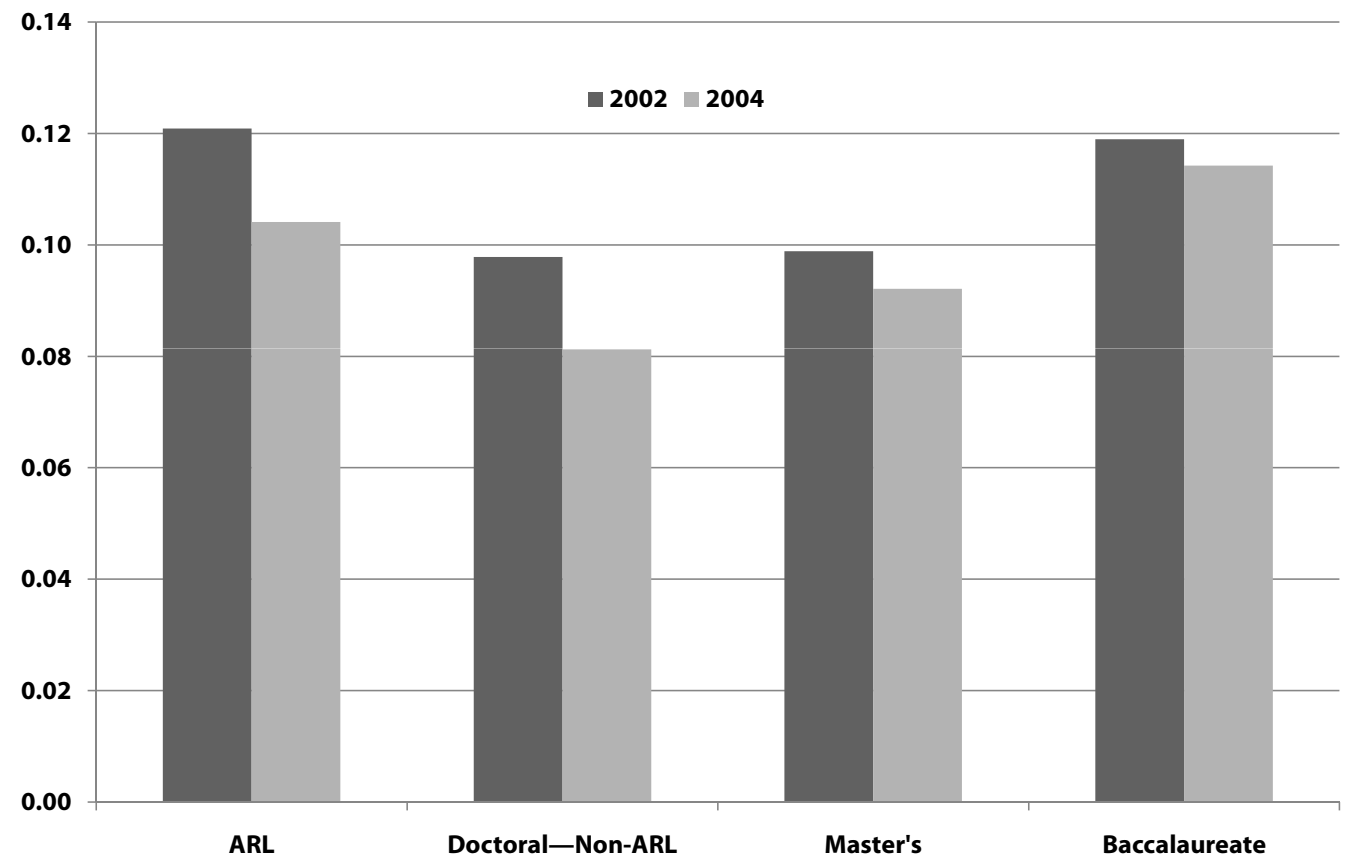

It is impossible from this data set to identify smaller errors, if they have occurred, nor to distinguish an institution experiencing genuinely unusual growth or decline versus one that, as an example, reported 1,025 reference transactions per week in 2002 and 51,980 per week in 2004, and thus qualified as an outlier.

The major variables are the changes from 2002 to 2004 in overall reference transactions per week, per library; reference transactions per week, per FTE student; and reference transactions per week, per librarian. "Change" is the difference between 2004 and 2002 data, expressed as a percentage of 2002 data; a positive number indicates an increase in transactions from 2002 to 2004 (= (2004-2002)/2002)

\section{RESULTS}

\section{Change in Overall Reference Transactions Per Week Per Library}

For this library-level variable, descriptive data of averages and standard deviations are not reported here because they simply reflect the very large variation of institution size within each group (although size does vary between groups; on average, doctoral institutions are larger than masters, which are larger than baccalaureate). What is analyzed instead is the percent change in overall reference transactions per week. For example, if Library A reported 1,000 transactions in 2002, and 900 transactions in 2004, it experienced a 10\% drop (relative to 2002). So has Library B, if it saw 400 in 2002, and 360 in 2004.

The data show that there has in fact been a decline in the number of reference transactions per week on a per-library basis across all institutional types. That is, comparing 2004 to 2002 figures, the average American academic library saw its overall number of transactions decline approximately 2.2\% (see table 3 and figure 1). Doctoral institutions, whether ARL members or not, have seen (or, more precisely, reported) distinctly larger drops in reference transactions. This appears to confirm reports of declines in traffic in libraries, particularly within the doctoral category.

\section{Reference Transactions Per Week Per FTE Student}

This variable adjusts for differing sizes of institutions (numbers of students). Therefore overall descriptive data for each category is provided in figure 2. Here we see that libraries at ARL and baccalaureate institutions have greater numbers of reference transactions per student.

Considering each institution's change in reference transactions (2004 as greater or less than 2002), each institution type experienced a decline 
Figure 3. Percent Change In Reference Transactions Per Week Per FTE Student

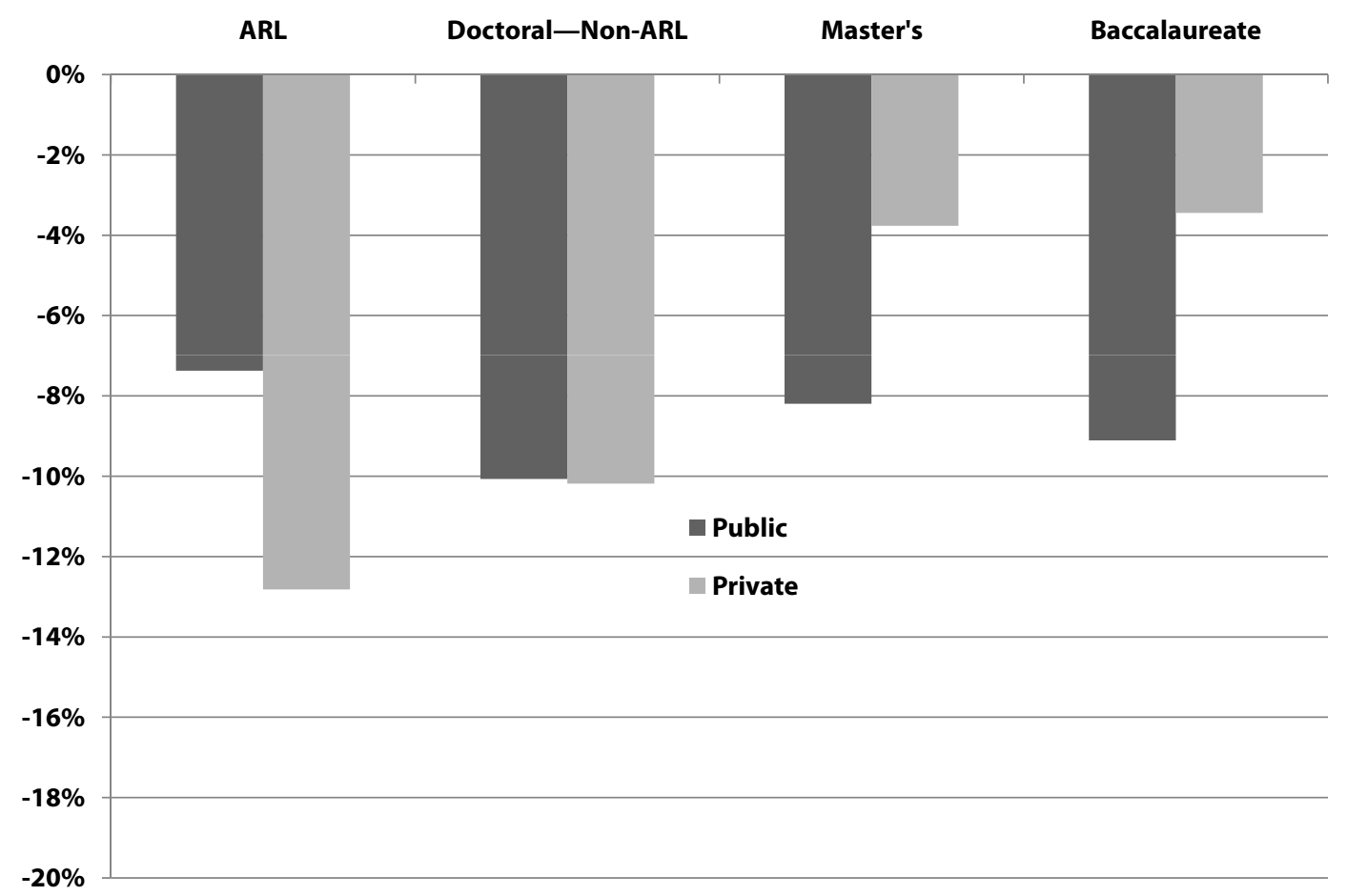

in transactions per student (see table 4). Again, ARL and doctoral institutions experienced the greatest percentage declines. Figure 3 shows the association with another institution variable, "control"public, private not-for-profit and private for-profit. Private masters and baccalaureate institutions witnessed the smallest decline; private ARL institutions, the largest.

\section{Reference Transactions Per Week Per Librarian}

The previous variables focused on the experiences (numerically expressed) of the library as a whole, and of an "average" student. The variable of reference transactions per week per librarian looks at the perspective of the "average" librarian. This data (figure 4) shows that the most intensive "reference work" on a per-librarian basis occurs at masters-level institutions-they handle roughly fifty questions per librarian while those in doctoral or baccalaureate institutions handle around forty student
Table 4. Change in Average Reference Transactions Per Week Per FTE

\begin{tabular}{lcc} 
Type of Institution & Average Change & Standard Deviation \\
ARL & $-9.2 \%$ & $27.7 \%$ \\
Doctoral-non ARL & $-10.1 \%$ & $30.8 \%$ \\
Masters & $-5.6 \%$ & $27.4 \%$ \\
Baccalaureate & $-3.4 \%$ & $29.9 \%$ \\
Total & $-5.6 \%$ & $28.9 \%$ \\
\hline
\end{tabular}

and those in ARL institutions around thirty. Notably, the graph shows that for librarians in masters institutions, their experience of reference transactions has NOT declined-they handled more on a per-librarian basis in 2004 than in 2002. Figure 4 is computed in this way:

- 2002 bar $=$ Average number of reference transactions per week in 2002, divided by the number of librarians in 2002, at each institution = 2002 Transaction/Librarian Ratio (T/L-R). The results were then averaged within each institutional category.

- 2004 bar = Average number of reference 
Figure 4. Average Reference Transactions Per Week Per Librarian

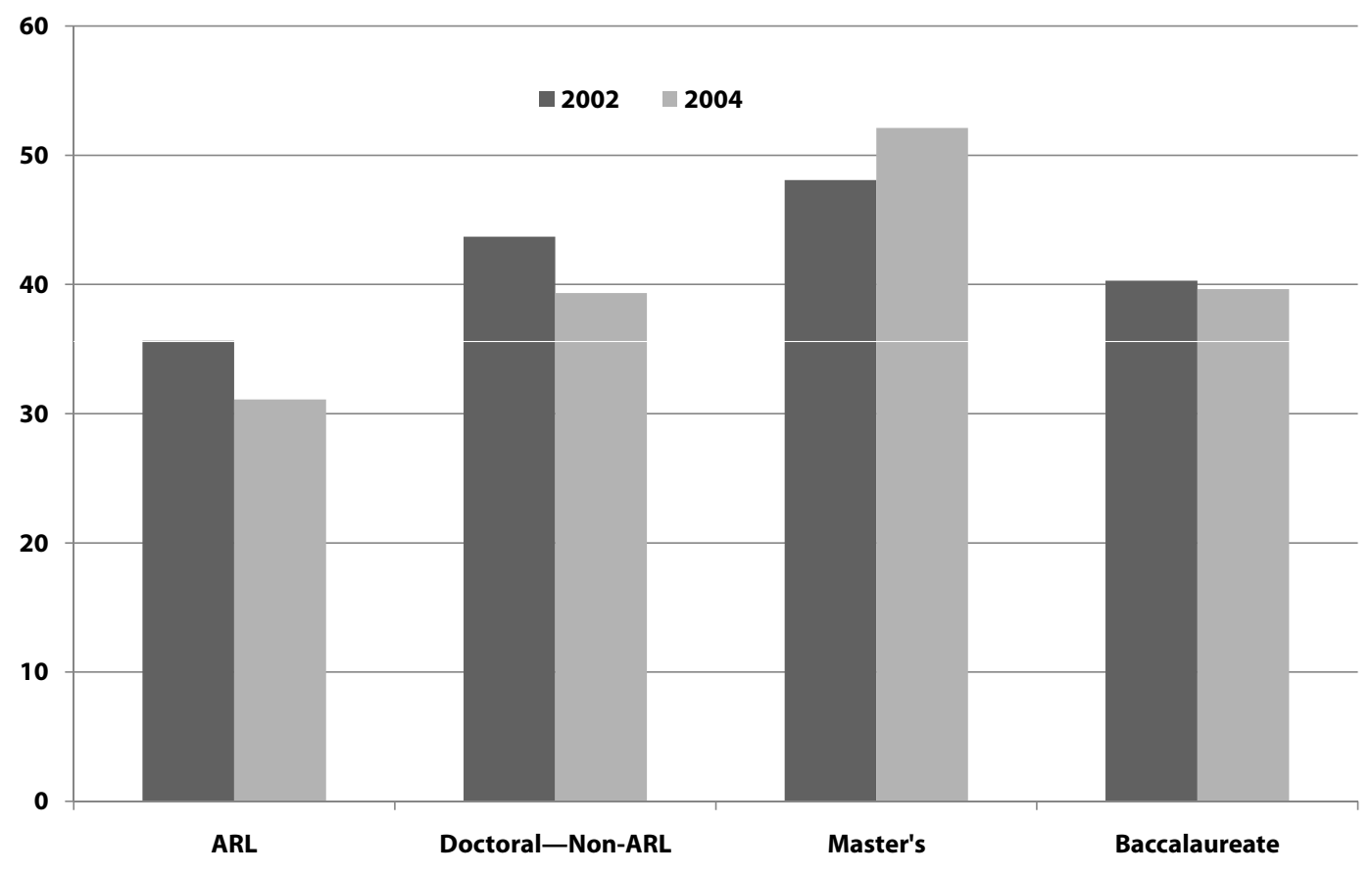

transactions per week in 2004, divided by the number of librarians in 2004, at each institution $=2004$ Transaction/Librarian Ratio (T/L$\mathrm{R})$

- The results were then averaged within each institutional category.

Figure 5 is based on a different calculation:

- [2004 T/L-R minus 2002 T/L-R] divided by the 2002 T/L R = how much the transactions-perlibrarian ratio has increased or decreased, as a percentage of the 2002 ratio. The results were computed for each institution, then averaged within each category.

What the latter comparison shows is that for an individual librarian, only the average ARL librarian has experienced a decline in reference transactions per week. In all other institution types, the ratio of questions to librarians has increased.

Neither this measure nor the underlying data set includes any indication of who actually answers reference questions in a particular library. Several models exist: direct staffing of most or all reference desk hours by MLS librarians; some hours or service points covered by graduate or undergraduate student workers; or some responsibilities held by reference paraprofessionals. Confining this ratio to librarians only rests on the logic of assuming that librarians have ultimate responsibility for reference services. In addition, overall results are similar when calculated on a denominator of total staff (librarians, other professionals, clerical, and student workers).

The distinct increase in numbers of questions per librarian differs from the decrease seen on a per-institution or per-student basis. A potential cause could be a change in the ratio of numbers of students to numbers of librarians. An increase in the number of students per librarian could result from either decreased numbers of librarians, or, as a student body grows, lack of a corresponding increase in librarians. The data shows that this ratio has in fact increased for all institution types-most for masters institutions and least for ARL libraries (see figures 6 and 7). When this control (student-to-librarian ratio) is introduced, it explains the difference between the questions-perlibrarian increase and the questions-per-institution or questions-per-student decrease.

Is there a decline? In sum, the answer to question 1 is that reference transactions do seem to be in a decline in all types of libraries, but to the greatest degree in ARL and other doctoral institutions. This is true from the institution's perspective when looking at one college or university's overall traffic and also from the student perspective when measuring how many questions are posed per student. 
Figure 5. Percent Change In Reference Transactions Per Week Per Librarian as Percent of 2002

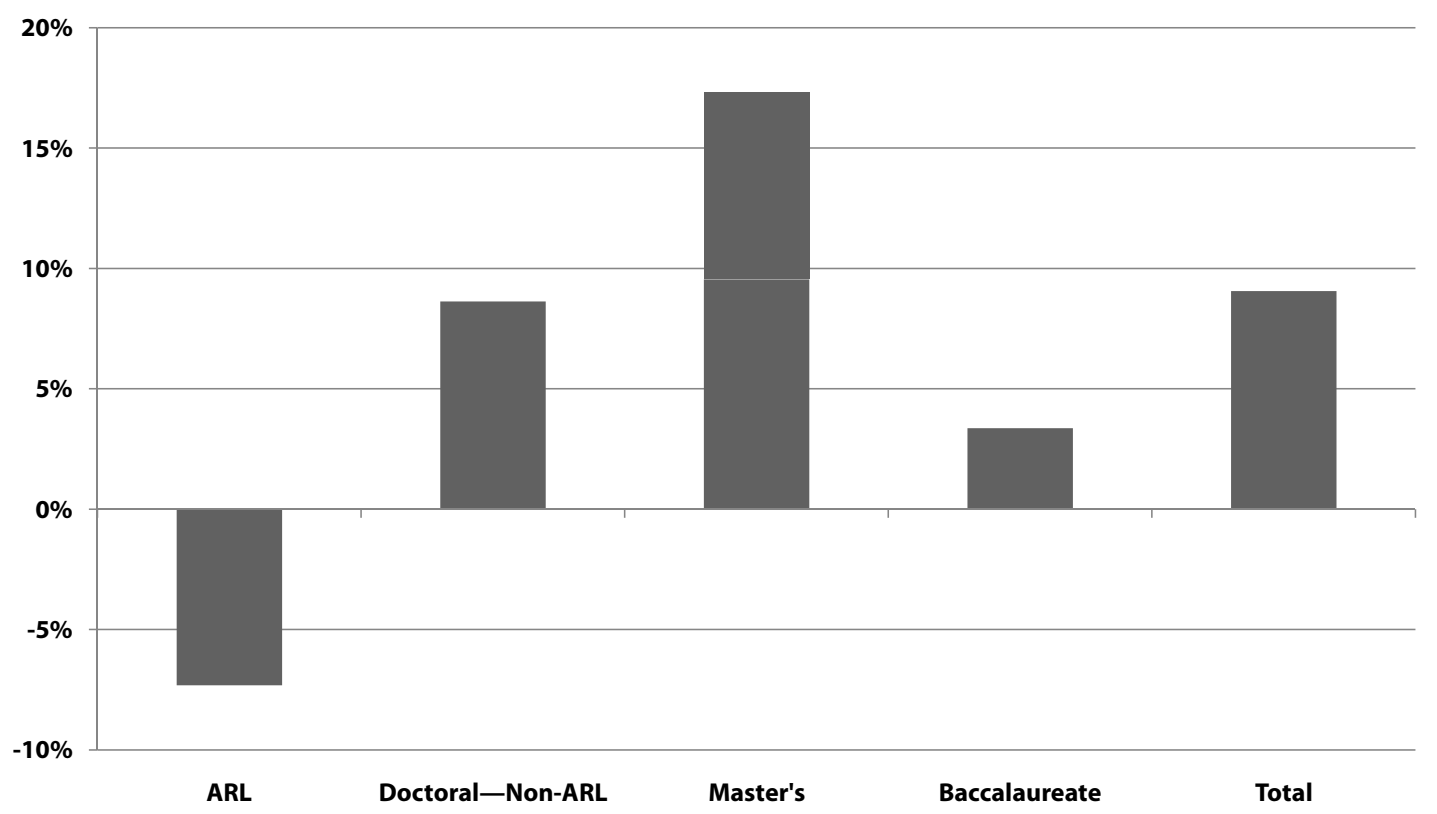

On the other hand, individual librarians in most types of institutions are probably not experiencing a decline but rather an increase in the numbers of questions each individual handles. Numbers of librarians relative to numbers of students for most institution types are down, well over 5\% except for ARL libraries. Consequently, the question-librarian ratio in all but ARL libraries has actually increased over the two-year period. This suggests that librarian numbers, especially in masters institutions, are diverging from actual demand.

Question 2 was about institution type: Is any observation the same across all academic libraries or does it differ by type? This study reports a "statistically significant" difference by type for all withinyear comparisons of study variables, and most "difference" (2004 vs. 2002) variables. This supports the importance of this categorical variable.

The data examined here is from a census, not a sample. Tests of statistical significance are generally intended to estimate the likelihood that results from a sample (for example, a higher average for one institution type than for another type) would be the same if the entire population were studied. That is not the situation here. Still, the ANOVA (analysis of variance) test of statistical significance can also be thought of, roughly, as a measure comparing the difference between variation within a group as well as variation between groups. Where within-group variation in a sample (and thus presumed in a population) is very large, betweengroup variations need to be correspondingly large to outweigh the within-group variation.

Examining this data pool with ANOVA shows that in each year's data, even though there is large variability (standard deviation) within each group, the differences between the groups-between institution types-show "p" values well under .05 , the usual criterion. That is, for each variable, the average value for each institution type (ARL, doctoral, masters, and baccalaureate) differs more from the other institution types (e.g., ARL versus doctoral, ARL versus masters) more than values within the categories differ from each other, even though there is considerable variation within each group. This supports the idea that institution type is an important factor when considering reference activity (and perhaps a wider range of other variables).

\section{DISCUSSION}

These data demonstrate that a decline is indeed detectable in the most commonly used measures of reference activity in academic libraries. They also show that the rate and experience of this decline vary considerably by institution type-ARL, doctoral, masters, baccalaureate, as well as public or private status-and so indicate that different academic librarians can honestly report that their own lived experiences testify either to decline or, often, to increases.

There has been a great deal of speculation about possible causes of changes in reference activities. Three potential issues are discussed here, 
Figure 6. Average FTE Students Per Librarian

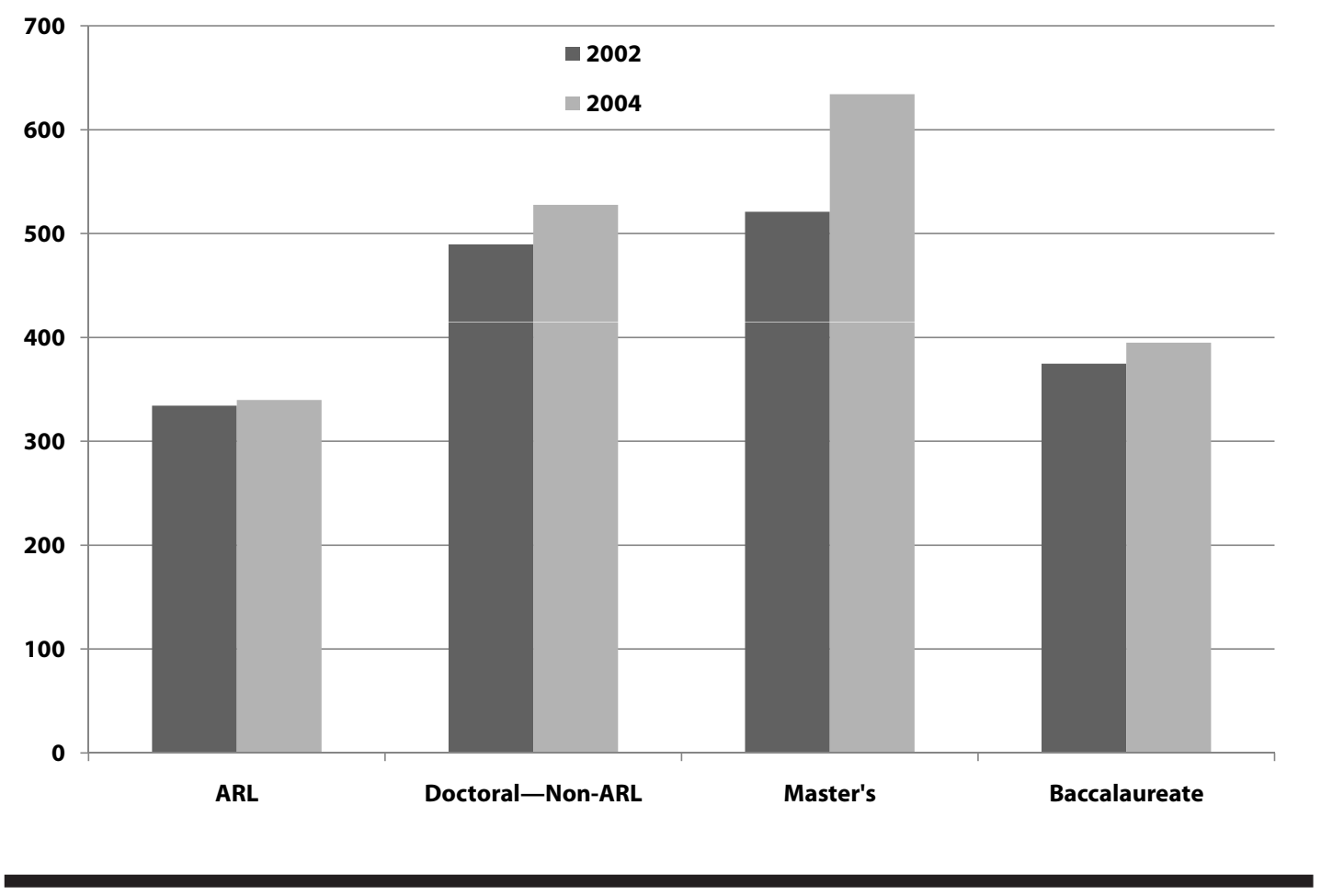

Figure 7. Percent Change In FTE Students Per Librarian as Percent of 2002

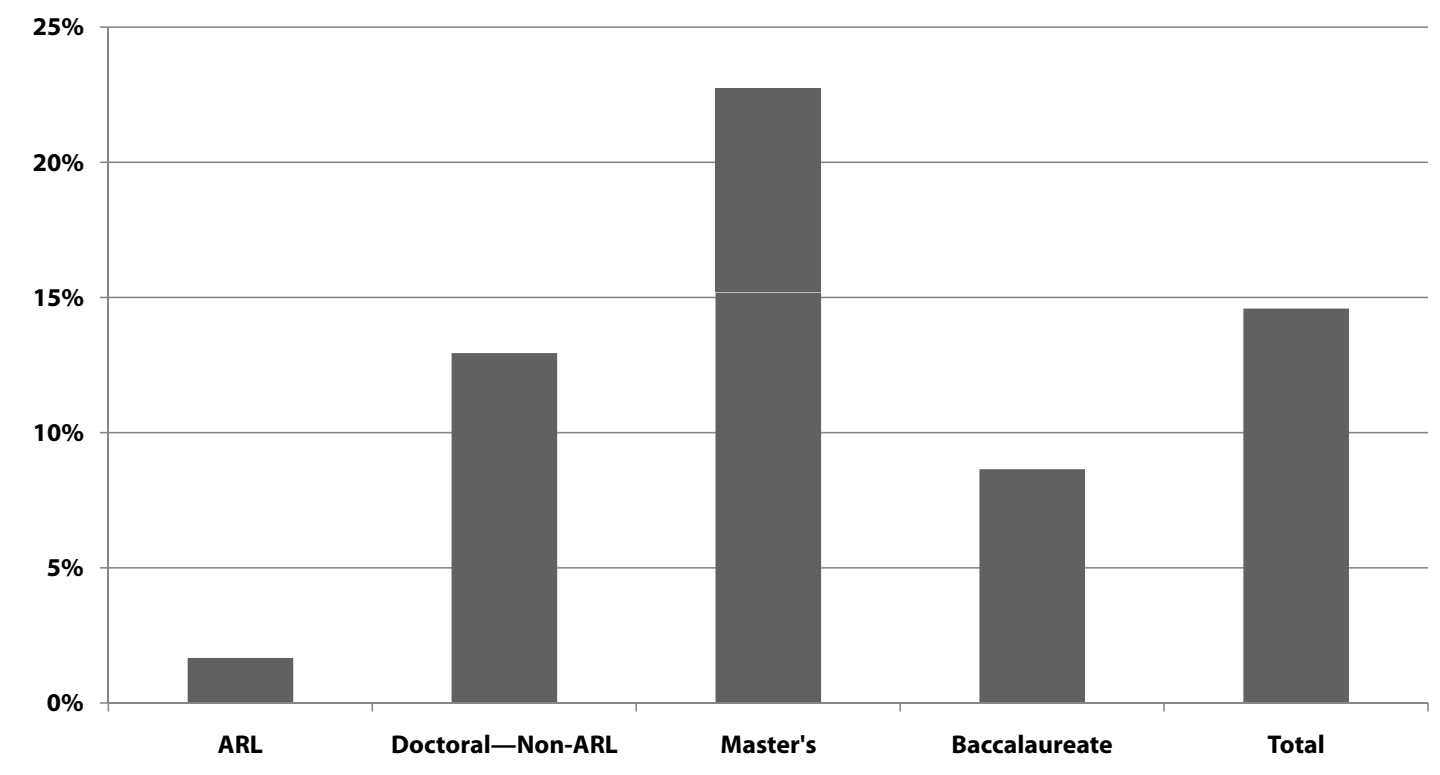

each with special relevance to academic libraries and perhaps different relevance to various academic library types. These issues are self-help, liaison programs, and virtual reference services.

Michael Gorman has speculated that the pool of reference questions has perhaps shifted, with fewer easy and more complex questions. ${ }^{25}$ "Selfhelp," or the ability of (potential) library users to find his or her own information, must surely affect academic libraries. It is well known that 
Table 5. Source of Data for Articles Published in Leading Journals, 2003-06

\section{Articles Containing Data}

\begin{tabular}{|c|c|c|c|c|}
\hline Journals & Total & $\begin{array}{c}\text { From U.S. } \\
\text { Colleges }\end{array}$ & From ARL & $\begin{array}{c}\text { ARL as } \% \text { of } \\
\text { College }\end{array}$ \\
\hline College \& Research Libraries & 93 & 52 & 35 & $67 \%$ \\
\hline Journal of Academic Librarianship & 119 & 79 & 37 & $47 \%$ \\
\hline Reference E User Services Quarterly & 33 & 16 & 9 & $56 \%$ \\
\hline Library Quarterly & 29 & 10 & 4 & $40 \%$ \\
\hline
\end{tabular}

many Americans use the Internet-not librariesas their initial resource for many issues, such as health, college search, and shopping. ${ }^{26}$

Information literacy programs should also be considered a form of self-help. Over the past ten years, as regional institutional accrediting agencies have revised their standards, more colleges and universities have incorporated explicit information literacy student learning outcomes into their educational requirements. Among other things, teaching students how to find information on their own can be reasonably predicted to result in a decline in at least some types of reference questions.

An anecdote illustrates this, with a tiny amount of data that may nevertheless reflect many librarians' experience. At a small institution one fall, a psychology professor neglected to schedule the usual class presentation on finding a research article. The librarians staffing the reference desk kept a tally of students requesting assistance with this particular assignment. The class in question had forty students; the reference staff reported that they were approached for help with this assignment forty-one times. With an in-class library instruction session, there would have been some, but surely fewer, questions.

Liaison programs may also be a factor. Over the past twenty years or so, academic librarians have advocated and researched the effectiveness of programs that increase communication between faculty and librarians. ${ }^{27}$ This is usually designed to improve collection development and the provision of bibliographic instruction, but increased communication may also affect the information-seeking behaviors of the faculty themselves. They may choose these developed communication channels over formalized reference services to express and find satisfaction for their own questions.

Finally, virtual reference services such as email, IM, or chat have been developed by individual libraries and consortia in the last ten years. ${ }^{28}$ In one respect this is a boon to research. Ironically, the more virtual the encounter, the easier it is to record and review, in contrast to the physical yet difficult-to-capture in-person encounter. Charles Martell argues strongly and directly that "reference transactions will probably remain soft until on-line reference services appear in full force." ${ }^{\text {29 }}$

This may be a more questionable assumption than it appears. Several recent studies of chat and e-mail reference services have reported quantities of e-transactions that are very small relative to overall reference traffic. A 2006 study of the discontinuation of nine of these services found that the top reason cited was "funding problems" followed by "low volume," which was probably relevant to the funding decisions. ${ }^{30} \mathrm{~A}$ study at an American university in 2002 showed only 342 questions total for January through August; 41\% of the questions were about library policy, and only thirteen were classified by the researchers as research questions. ${ }^{31}$ A study of international academic libraries (located respectively in Israel, Lebanon, and Japan) showed one library with two e-mail questions per day compared to three hundred in-person questions; another, one hundred in-person questions per day and less than one email (four per week); the final showed five virtual inquiries per month. ${ }^{32}$

These issues and the detectable differences between institution types suggest a hard road ahead for reference research. It is notoriously challenging to measure the "difficulty" or even the time consumed by reference transactions, though the suggestion that reference question types may be significantly changing is not to be dismissed.

What merits greater emphasis is attention to differences between libraries. Academic library literature is heavily weighted to coverage of research libraries. Between 2003 and 2006 at least $40 \%$ of articles published in four leading journals, using data from U.S. academic libraries, were focused entirely or more than half on ARL institutions (see table 5). ${ }^{33}$ This is disproportionate to academic 
library numbers (and populations served) and, as this study's data shows, can be unrepresentative of the experiences of librarians in other types of institutions.

ARL libraries have specific and distinctive missions in common-in fact, the existence of their organization testifies to this. They would not have felt it important to work together without a sense of commonality that separates them from other academic libraries. Two items can illustrate this, one an inclusion (collections) and one an omission (library instruction). Criticized as a "narrow" criterion for evaluation today, ARL libraries have always considered collections important, indeed essential to their conception of their role in academia and librarianship. The ARL Index from the beginning has focused on collection strength and continues to weigh it strongly. In contrast, the ARL-developed LibQUAL+ survey omits from its core set of questions bibliographic instruction, which it terms a "local" matter. ${ }^{34}$ User instruction is something that many smaller academic librarieswho never considered themselves committed to collection comprehensiveness-view as essential to their role and existence.

A fruitful approach to understanding the future of reference in academic libraries can include the following: studying a wider range of in-library and out-of-library information-seeking activities; broadening and deepening — and in some cases abandoning - the definition of "transaction"; and incorporating a sensitivity to the differing missions, cultures, and activities of the variety of academic institutions for which the American system of higher education is justifiably famous.

\section{References and Notes}

1. Scott Carlson, "The Deserted Library: As Students Work Online, Reading Rooms Empty-Leading Some Campuses to Add Starbucks," Chronicle of Higher Education (Nov. 16, 2001): A1, A35.

2. Andrew R. Albanese, "Deserted No More," Library Journal 128, no. 7 (Apr. 15, 2003): 34-36.

3. Charles Martell, "Guest Editorial: The Ubiquitous User: A Reexamination of Carlson's Deserted Library," portal: Libraries and the Academy 5, no. 4 (Oct. 2005): 441-53.

4. Barbara Fister, "Common Ground: Libraries and Learning," Library Issues: Briefings for Faculty and Administrators 25 (2004).

5. Martha Kyrillidou and Mark Young, eds. ARL Statistics 2004-2005 (Washington, D.C.: Association of Research Libraries, 2006), www.arl.org/bm doc/ arlstat05.pdf (accessed June 15, 2007).

6. Harold B. Shill and Shawn Tonner, "Does the Building Still Matter? Usage Patterns in New, Expanded, and Renovated Libraries, 1995-2002," College \& Research Libraries 65, no. 2 (Mar. 2004): 123-50.

7. James L. Mullins, Frank R. Allen, and Jon R. Hufford,
"Top Ten Assumptions for the Future of Academic Libraries and Librarians: A Report from the ACRL Research Committee," College \& Research Libraries News 68, no. 4 (Apr. 2007): 240-41, 46.

8. Martha Kyrillidou, 2004-05 ARL Membership Criteria Index (Principal Component Scores)—Revised Document (Washington, D.C.: ACRL, 2006), www.arl.org/ bm doc/index05.pdf (accessed June 15, 2007).

9. Rachel Applegate, "Charting Academic Library Staffing: Data from National Surveys," College \& Research Libraries 68, no. 1 (Jan. 2007): 59-68.

10. Robert W. Christ, "Recording Reference Service," College \& Research Libraries 8 (1947): 23-27; Marcella Ciucki, "Recording of Reference/Information Service Activities: A Study of Forms Currently Used," RQ 16 (1977): 273-322; Katherine Emerson, "National Reporting on Reference Transactions, 1976-78," RQ 16 (1977): 199-207.

11. For example, Michael Halperin, "Cluster Sampling Reference Transactions," RQ 17 (1978): 328-33.

12. For example, Howard White, "Measurement at the Reference Desk," Drexel Library Quarterly 17 (1981): 3-35.

13. Rhonda Boyd, "Assessing the True Nature of Information Transactions at a Suburban Library," Public Libraries 44, no. 4 (July/Aug. 2005): 234-40.

14. Marilyn Shontz, "Measuring Reference Transactions in the School Library Media Program," Reference Librarian 44 (1994): 145-60.

15. Reference Service Statistics and Assessment: Executive Summary: Spec Kit 268 (Washington, D.C.: Association of Research Libraries, 2002).

16. John V. Richardson, "The Current State of Research on Reference Transactions," Advances in Librarianship 26 (2002): 178, 183, 218.

17. Matthew L. Saxton and John V. Richardson, Understanding Reference Transactions: Transforming an Art into a Science (New York: Academic Pr., 2002).

18. Marjorie Murfin and Fred Ruland, "Measurement of Reference Transactions: An in-Depth Statistical Study of Demand and Capacity in Twenty-Two [University Branch] Libraries over a Two-Year Period," Library Effectiveness: A State-of-the-Art (New York: ALA/ Library Administration and Management Association, 1980): 194-209; Marjorie E. Murfin, "National Reference Measurement: What Can It Tell Us About Staffing?" College E Research Libraries 44 (1983): 321-33.

19. Beth J. Shapiro, "Access and Performance Measures in Research Libraries in the 1990's," Journal of Library Administration 15 (1992): 49-66; Sharon A. Weiner, "Library Quality and Impact: Is There a Relationship between New Measures and Traditional Measures?" Journal of Academic Librarianship 31, no. 5 (Sept. 2005): 432-37.

20. Gwenn Lochstet and Donna H. Lehman, "A Correlation Method for Collecting Reference Statistics," College \& Research Libraries 60, no. 1 (Jan. 1999): 45-53.

21. Wanda V. Dole, Jitka M. Hurych, and Anne Liebst, "Assessment: A Core Competency for Library Leaders," Library Administration and Management 19 (2005): 125-32.

22. This information comes from unpublished data from eight Indiana academic libraries.

23. National Center for Education Statistics, Library Statistics Program: Compare Academic Libraries, http://nces.ed.gov/surveys/libraries/compare/index 
asp?LibraryType=Academic (accessed June 17, 2007).

24. See Don A. Dillman, Mail and Internet Surveys: The Tailored Design Method, 2007 Update with New Internet, Visual, and Mixed-Mode Guide, 2nd ed. (Hoboken, N.J.: Wiley, 2007): 77.

25. As quoted in Albanese, "Deserted No More," 35-36.

26. See, for example, John Horrigan and Lee Rainie, "The Internet's Growing Role in Life's Major Moments," Pew Internet and American Life Project, www.pewinternet .org/PPF/r/181/report_display.asp (accessed June 17, 2007), as well as other Pew research reports.

27. See a review in Donald G. Frank and Elizabeth A. Howell, "Information Consulting in Academe," Encyclopedia of Library and Information Science (New York: Marcel Dekker, 2003), 1294-99; and an example in Ada M. Ducas and Nicole Michaud-Oystryk, "Toward a New Enterprise: Capitalizing on the Faculty-Librarian Partnership," College \& Research Libraries 64, no.1 (Jan. 2003): 55-74.

28. Bernie Sloan, "Twenty Years of Virtual Reference," Internet Reference Services Quarterly 11, no. 2 (2006): 91-95.
29. Martell, "Guest Editorial: The Ubiquitous User," 444.

30. Marie L. Radford and M. Kathleen Kern, "A MultipleCase Study Investigation of the Discontinuation of Nine Chat Reference Services," Library \& Information Science Research 28, no. 4 (2006): 521-47.

31. Julie Arnold and Neal Kaske, "Evaluating the Quality of a Chat Service," portal: Libraries and the Academy 5, no. 2 (Apr. 2005): 177-93.

32. Pnina Shachaf, Lokman Meho, and Noriko Hara, "Cross-Cultural Analysis of E-Mail Reference," Journal of Academic Librarianship 33, no. 2 (Mar. 2007): 243-53.

33. That is, when a single institution was involved, it was an ARL library. Where a group of institutions was involved, at least half of the members of the groups were ARL members. Not included in the ARL count are surveys or studies of academic libraries in general.

34. Bruce Thompson, Colleen Cook, and Martha Kyrillidou, "Using Localized Survey Items to Augment Standardized Benchmarking Measures: A Libqual $+{ }^{\mathrm{TM}}$ Study," portal: Libraries and the Academy 6 (2006): 219-30.

\section{APPENDIX: REFERENCE TRANSACTION DEFINITION}

Current Definition: National Center for Education Statistics, Library Statistics Program: Compare Academic Libraries (Washington D.C.: U.S. Department of Education, 2007), http://nces.ed.gov/surveys/libraries/ compare/Index.asp(accessed June 15, 2007).

1977 Definition: Emerson, Katherine. "National Reporting on Reference Transactions, 1976-78." RQ 16 (1977): 199-207.

Wording new to the current definition is in all caps. Original (1977) wording is given in brackets; "instead" means it was replaced by the current wording; "added" means that the 1977 definition contained that wording and the current definition does not.

\section{Reference Transactions in a Typical Week}

Definition: Total number of reference transactions in a typical week. A reference transaction is an information contact that involves the knowledge, use, COMMENDATION [1977 instead: recommendation], interpretation, or instruction in the use of one or more information sources [1977 adds: or knowledge of such sources] by a member of the LIBRARY STAFF [1977 instead: reference/information staff and a user]. Information sources include printed and non-printed materials, machine-readable databases (including ASSISTANCE WITH COMPUTER SEARCHING) [1977 instead: (including computer-assisted instruction)], THE WEB, CATALOGS AND OTHER HOLDINGS RECORDS [1977 instead: library bibliographic records, excluding circulation records; ], and, THROUGH COMMUNICATION OR REFERRAL, other libraries and institutions, and persons both inside and outside the library. INCLUDES TRANSACTIONS IN PERSON, BY PHONE, BY E-MAIL, BY THE WEB, AND COUNT TRANSACTIONS THAT TAKE PLACE AT THE REFERENCE DESK, AS WELL AS ELSEWHERE. INCLUDES INFORMATION AND REFERRAL SERVICES. IF A CONTACT INCLUDES BOTH REFERENCE AND DIRECTIONAL SERVICES, IT IS REPORTED AS ONE REFERENCE TRANSACTION. WHEN A STAFF MEMBER UTILIZES [1977 instead: A question answered through utilization of] information gained from A PREVIOUS USE OF [1977 instead: previous consultation of such] information sources to answer a question, THIS IS REPORTED [1977 instead: is considered] as a reference transaction, even if the source is not consulted again DURING THIS TRANSACTION. DURATION SHOULD NOT BE AN ELEMENT IN DETERMINING WHETHER A TRANSACTION IS A REFERENCE TRANSACTION. 
DIRECTIONAL TRANSACTIONS ARE NOT INCLUDED HERE. [1977 instead: Report the total Directional Transactions per typical week]. A directional transaction is an information contact which facilitates the use of the library in which the contact occurs [1977: and its environs,] AND WHICH DOES NOT INVOLVE THE KNOWLEDGE, USE, RECOMMENDATION, INTERPRETATION, OR INSTRUCTION IN THE USE OF ANY INFORMATION SOURCES OTHER THAN THOSE WHICH DESCRIBE [1977 instead: which may involve the use of sources describing that] THE library; such as schedules, floor plans, handbooks, and policy statements. Examples of directional transactions INCLUDE [1977 instead: are (1977 uses numbering)] GIVING INSTRUCTION IN LOCATING, WITHIN THE LIBRARY [1977 instead: directions for locating facilities such as restrooms, carrels, and telephones; directions for locating] staff [1977: and] LIBRARY users, OR PHYSICAL FEATURES, ETC. [1977 adds: directions for locating materials for which the user has a call number; supplying materials such as paper and pencils]; AND GIVING ASSISTANCE OF A NONBIBLIOGRAPHIC NATURE WITH MACHINES [1977 instead: assisting users with the operation of machines.]

INDEX TO ADVERTISERS

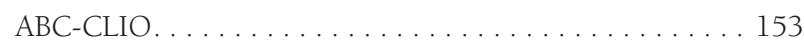

Annual Reviews. . . . . . . . . . . . . . . . . . . 175

Compendium

Hoover's cover 2

H. W. Wilson. .......................... cover 3
MLA ............................. 109

Omnigraphics ......................... cover 4

Plunkett Research Ltd. . . . . . . . . . . . . . . . insert

Sharpe Reference. . . . . . . . . . . . . . . . . . . . . 141 